\title{
PROTECTIVE EFFECTS OF MILDRONATE IN INDINAVIR- AND EFAVIRENZ-INDUCED TOXICITY IN MICE
}

\author{
Jolanta Pupure*, Sergejs Isajevs*, Ivars Kalviņš̌**, and Vija Kluša* \\ *Faculty of Medicine, University of Latvia, Šarlotes iela 1A, Rīga, LV-1001, LATVIA \\ E-mail: pupure@e-apollo.Iv \\ **Latvian Institute of Organic Synthesis, Aizkraukles iela 21, Rīga, LV-1006, LATVIA
}

Contributed by Vija Kluša

\begin{abstract}
Previously we showed that mildronate effectively protected mice heart tissue against the toxic influence of anti-HIV drugs azidothymidine, stavudine and lamivudine, which belong to nucleosideanalogue reverse transcriptase inhibitor (NRTI) class. Recently we also demonstrated that mildronate protected isolated rat liver mitochondria against mitochondrial damage caused by azidothymidine. The present study was devoted to examine the possible protective effectiveness of mildronate in cardio-, hepato- and neurotoxicity models caused by anti-HIV drugs of other classes: indinavir, a representative of protease inhibitor (PI) class, and efavirenz, a nonnucleoside-analogue reverse transcriptase inhibitor (NNRTI). Drugs were administered intraperitoneally for two weeks, at the dose of $50 \mathrm{mg} / \mathrm{kg}$ of anti-HIV drugs and $100 \mathrm{mg} / \mathrm{kg}$ for mildronate. Afterwards, mice heart, liver and brain tissue were examined morphologically and immunohistochemically. The results showed that indinavir in heart tissue caused inflammatory and degenerative changes, manifested as increased expression of nuclear factor kappaBp65 (NF-kBp65), as well as cardiomyocyte necrosis and cellular infiltration. Efavirenz did not cause pathological changes in mice heart tissue, whereas it induced marked expression of caspase-3 and glial fibrillary acidic protein (GFAP) in mice brain tissue and small degenerative alterations in mice liver tissue. The data obtained show mildronate's protective properties in indinavir-induced cardiotoxicity and efavirenz-induced neurotoxicity.
\end{abstract}

Key words: mildronate, indinavir cardiotoxicity, efavirenz neurotoxicity.

\section{INTRODUCTION}

Our previous pharmacological studies have shown that mildronate, a well-known cardioprotective drug, has an ability to protect tissues from toxic influence of anti-HIV drugs that belong to nucleoside-analogue reverse transcriptase inhibitor (NRTI) class, such as azidothymidine, stavudine and lamivudine (Klusa et al., 2006; Isajevs et al., 2007). Their side effects mostly are caused via deteriorating influence on mitochondrial processes (White, 2001), however, organtoxicity depends on the drug used. For example, azidothymidine is characterised by its strong cardiotoxic effects, which is documented either in experiments or clinical studies (Peters et al., 1992; Corcuera Pindado et al., 1994; Szabados et al., 1999), while stavudine therapy can induce hepatic steatosis and lactic acidosis (Miller et al., 2000), which is less expressed for lamivudine (Caron et al., 2008).

In the present study, we designed experiments to evaluate the influence of mildronate on indinavir- and efavirenz-induced toxic effects in mice cardiac tissue; additionally, efavirenz toxicity was also assessed in mice liver and brain tissues. Immunohistochemical studies were focused on tran- scription factor - nuclear factor $\kappa B p 65$ (NFkBp65), as well as active caspase-3, and glial fibrillary acidic protein (GFAP). NF- $\kappa \mathrm{B}$ is involved in inflammatory responses by stimulating the production of proinflammatory cytokines, including interleukins (IL-1 and IL-6), inducible cyclooxygenase, and inducible nitric oxide synthase (Rahman and MacNee, 2000). Therefore, cellular activation and an increase in inflammatory mediator synthesis indicate that NF-KB is activated (Di Stefano et al., 2002). Caspase-3 is a central key enzyme in many cells, leading to DNase activation, followed by DNA fragmentation (Enari et al., 1998). In normal cells, caspase-3 exists as a procaspase in which the potential cleavage site is intact. Once cleaved through the activation of the apoptotic cascade, the peptide end of this active caspase represents a novel epitope which is not presented in normal cells. Therefore, the detection of this novel epitope is a unique and sensitive indicator of apoptosis (Gown and Willingham, 2002). GFAP is a significant structural protein of glial astrocytes, which provide neuronal-glial-vascular signal transduction (Allen and Barres, 2009). In addition, GFAP is increased in various pathologies and thus may be used as a marker of neuronal and glial damage (Holmberg et al., 1998; Tullberg et al., 1998). 
The aim of this study was to evaluate whether mildronate exerts protective effects also in toxicity models obtained by anti-HIV drugs of other classes, such as non-nucleoside analogue reverse transcriptase inhibitors (NNRTI) and protease inhibitors (PI). We suggested that this study may broaden the spectrum of protective action of mildronate. For this purpose, we chose two anti-HIV drugs: indinavir and efavirenz, representatives of PI and NNRTI classes, respectively. In vitro studies on adipocytes showed indinavir to worsen mitochondrial function (Viengchareun et al., 2007). Furthermore, in a myoblast cell line it caused multiple defects in translation initiation affecting protein synthesis (Hong-Brown et al., 2004). In comparison to other reverse transcriptase inhibitors, efavirenz in a human hepatoma cell line did not cause mitochondrial toxicity (Walker et al., 2002). However, it affected liver function (Kontorinis and Dieterich, 2003), and in mice brain tissue inhibited creatine kinase activity, indicating central nervous system toxicity (Streck et al., 2008).

\section{MATERIALS AND METHODS}

Chemicals. Indinavir $(2 S)-1-[(2 S, 4 R)-4$-benzyl-2-hydroxy4- $\{[(1 S, 2 R)$-2-hydroxy-2,3-dihydro- $1 H$-inden-1-yl $]$ carbamo yl \}butyl]- $N$-tert-butyl-4-(pyridin-3-ylmethyl)piperazine2-carboxamide), Crixivan* as $400 \mathrm{mg}$ capsules was manufactured by Merck Sharp \& Dohme Ltd (UK) and efavirenz ((4S)-6-chloro-4-(2-cyclopropylethynyl)-4-(trifluoromethyl) -2,4-dihydro-1H-3,1-benzoxazin-2-one), Sustiva* as 100 mg capsules by Bristol-Myers Squibb (UK). Mildronate [3-(2,2,2-trimethylhydrazinium) propionate dihydrate], was synthesised at the Latvian Institute of Organic Synthesis, and manufactured by the Joint Stock Company Grindex (Riga, Latvia). Mildronate was dissolved in saline and prepared as a $2 \%$ stock solution. A water suspension of indinavir and efevirenz ( $1 \%$ stock suspension) was made by adding 1-2 drops of $0.6 \%$ TWIN-80, and then diluted by saline to an appropriate concentration. The NF-кBp65 rabbit polyclonal antibody (AbCam, UK), dilution 1 : 200; active caspase-3 rabbit polyclonal antibody (AbCam, UK) was used in a dilution 1:100; and rabbit polyclonal to glial fibrillary acidic protein (GFAP) — astrocyte marker antibody (DAKO, Denmark), a dilution 1 : 500. Peroxidase conjugated polyclonal goat anti-rabbit IgG and polyclonal rabbit anti-goat $\mathrm{IgG}$, serum-free protein block, citrate buffer, $0.5 \% \mathrm{H}_{2} \mathrm{O}_{2}$ and diaminobenzidine were from Dako, Denmark.

Animals. Animals (male ICR mice) were obtained from the Laboratory of Experimental Animals, Rīga Stradiňš University, Latvia, each weighing $17.0 \pm 0.1 \mathrm{~g}$ at the beginning of experiment. The environment was maintained at a temperature of $22.0 \pm 0.5{ }^{\circ} \mathrm{C}$ with a 12 -h light/dark cycle. Rats were fed a standard laboratory diet.

Experiment design. The experiment was carried out in mice by daily intraperitoneal administration of both mildronate and indinavir or efavirenz for two weeks. Mildronate was used at $100 \mathrm{mg} / \mathrm{kg}$ (a dose that we previously found to be the most effective in experiments with azidothymidine (Klusa et al., 2006); indinavir and efavirenz at 50 $\mathrm{mg} / \mathrm{kg}$ (similar azidothymidine dose was administered in previous experiments (Klusa et al., 2006). Drugs were injected in a volume of $10 \mathrm{ml} / \mathrm{kg}$ intraperitoneally in both left and right sides of the following mice groups (eight animals per group):

Group 1: saline (left side) + saline (right side);

Group 2: mildronate (left) + saline (right);

Group 3: saline (left) + efavirenz (right);

Group 4: saline (left) + indinavir (right);

Group 5: mildronate (left) + efavirenz (right);

Group 6: mildronate (left) + indinavir (right).

On day 15 , mice were sacrificed by decapitation. Cardiac tissue, as well as liver and brain tissue for the efavirenz group were removed and fixed in $10 \%$ neutral buffered formalin, processed and embedded routinely.

Immunohistochemical examination. For immunohistochemistry, paraffin-embedded tissue was cut in 4-micronthick sections. According to the immunohistochemical method described elsewhere (Di Stefano et al., 2002), tissue sections were stained for visualisation of NF- $\kappa$ Bp65 positive cells (nuclear immunostaining), and caspase-3, and GFAP positive cells (cytoplasmic immunostaining). Briefly, antigen retrieval was achieved by treatment in a microwave for $20 \mathrm{~min}$ at $300 \mathrm{~W}$ in citrate buffer, $\mathrm{pH}=6.0$. Endogenous peroxidase activity was blocked by $0.5 \% \mathrm{H}_{2} \mathrm{O}_{2}$ for 10 minutes. Nonspecific primary antibody binding was blocked by serum-free protein block for 10 minutes. Rabbit polyclonal NF- $\kappa$ Bp65 antibody was applied at $1: 200$ and incubated overnight at $4{ }^{\circ} \mathrm{C}$. Active caspase- 3 and GFAP antibodies were applied at $1: 200$ and $1: 500$, respectively, and incubated for 1 hour at room temperature. Detection of primary antibody binding was performed using specific peroxidase conjugated polyclonal goat anti-rabbit IgG (at $1: 100$ for $30 \mathrm{~min}$ ) and subsequently peroxidase conjugated polyclonal rabbit anti-goat $\operatorname{IgG}$ at $1: 100$ for 30 minutes. The immunoperoxidase colour reaction was developed by incubation with diaminobenzidine $(5 \mathrm{~min})$. A negative control without primary antibody was included in each staining run. NF- $\mathrm{BBp} 65$ nuclear immunolocalisation in cardiomyocytes, inflammatory and endothelial cells, as well as caspase- 3 cytoplasmic immunolocalisation in cardiomyocytes and hepatocytes, and GFAP cytoplasmic immunolocalisation in neuronal cells, respectively, were counted using image analysis software in ten high-powered fields (at magnification $\times 400$ ), and their total number was recorded. All cell counts were expressed as cells per $\mathrm{mm}^{2}$. Slides were coded and counted by two pathologists in blinded fashion. Cardiac tissue sections were counterstained with haematoxylin eosin to allow the identification of NF- $\mathrm{Bp} 65$ positive cells of different lineages by their anatomic features: cell nuclear size and shape, spatial arrangement and 
distribution. Thus, the cardiomyocyte origin of the $\mathrm{NF}-\kappa \mathrm{Bp} 65$ positive nuclear immunolocalisation was confirmed by the presence of myofilaments in the cytoplasm. Anatomically cells lying freely either in capillary lumina or interstitium were considered as infiltrating leukocytes. Only elongated cells lying along the inner walls of vessels were defined as endothelial cells. However, differentiation of different lineages of NF- $\kappa \mathrm{Bp} 65$ positive cells was possible in transverse but not in cross sections. Therefore, we assessed the total number of cells with NF-кBp65 nuclear staining.

According to the intensity of NF- $\kappa \mathrm{Bp} 65$, caspase-3 or GFAP positive staining, three types of staining patterns were mainly observed: unstained, lightly and strongly stained. For counting, only cells that showed strong staining were regarded as positive.

Morphological examination. Paraffin-embedded tissue was cut in 4-micron-thick sections and stained with haematoxylin and eosin for morphological examination.

The extent of myocardial necrosis was measured using a light microscope (Leica) coupled to an analysis system (Image ProPlus). Ten high-power fields at magnification $\times 400$ were captured (surface area of one high-power field at magnification $\times 400=0.229 \mathrm{~mm}^{2}$ ). The myocardial necrotic changes (early signs of coagulation necrosis) were identified by myocyte hypereosinophilia, pyknosis of nuclei, waviness of fibers at the border, interstitial oedema, no or occasional inflammatory cells in the interstitium, whereas a total coagulation necrosis was characterised by myocytes with shrunken eosinophilic cytoplasm, loss of nuclei and cross striation, accompanied by edema and inflammatory cell infiltration of the interstitium (Akasaka, 2006). The relevant area was outlined on a captured image and the necrotic area was measured. The results were expressed as a percentage of necrotic area (represented both early changes and coagulation necrosis) to the total area examined.

Cellular infiltration in heart tissue was assessed on a scale, where $0=$ no infiltration, $1=$ infiltration less than $25 \%, 2=$ infiltration between $25 \%$ and $50 \%, 3=$ infiltration between $50 \%$ and $75 \%$, and $4-$ infiltration more than $75 \%$ of analysed myocardial field; cardiomyocyte necrotic changes were expressed in percentage of the total myocardial field.

In brain tissue, we assessed infiltration of inflammatory cells, analysed according to regions (magnification $\times 400$ ): 1) subcortical perivascular, 2) subcortical parenchymal, and 3) intracortical perivascular. Perivascular infiltrates were defined as inflammatory cells, which are located not further than three cell layers from blood vessels. Inflammatory cells that were further than three layers from blood vessel wall were defined as parenchymal infiltrates. Infiltration of inflammatory cells was assessed according to a four score scale: 0 - no infiltration; 1 - light infiltration; 2 - medium infiltration; 3 - marked infiltration; 4 - very marked infiltration (more than $25 \%$ of the total field of vision).

Morphology of liver tissue was evaluated by assessing the histological activity index (HAI), according to Ishak et al.
(1995) with minor modifications: infiltration of inflammatory cells (0-4 scores); necrosis of hepatocytes around central vein (0-6 scores); necrosis of hepatocytes and apoptosis in lobular periphery (0-4 scores); inflammatory changes of portal tracts ( $0-4$ scores).

Animal ethics. All experimental procedures were carried out in accordance with the guidelines of the Directive 86/609/EEC "European Convention for the Protection of Vertebrate Animals Used for Experimental and other Scientific Purposes" (1986) and were approved by the Animal Ethics Committee of the Food and Veterinary Service (Riga, Latvia).

Statistics. For statistical analysis GraphPad Prism 4 software was used. Results are expressed as the mean \pm SE values, and significance was set at $P<0.05$ (unpaired t-test or Mann-Whitney $U$ test for cellular infiltration scores).

\section{RESULTS}

Effect of mildronate on immunohistochemical and morphological changes in mice cardiac tissue. Indinavir (50 $\mathrm{mg} / \mathrm{kg}$ ) significantly increased $\mathrm{NF}-\kappa \mathrm{Bp} 65$ expression in mice cardiac tissue, in comparison to the control group $\left(103.4 \pm 10.4\right.$ vs. $34.7 \pm 2.8$ cells $/ \mathrm{mm}^{2}, P<0.0001$, Fig. 1$)$. Mildronate $(100 \mathrm{mg} / \mathrm{kg})$ per se did not change NF-кBp65 expression, in comparison to control values $(38.8 \pm 5.0$ vs. $34.7 \pm 2.8$ cells $\left./ \mathrm{mm}^{2}, P>0.05\right)$, whereas the combined mildronate administration with indinavir significantly lowered the indinavir-induced overexpression of NF- $\mathrm{KBp} 65$ $\left(49.6 \pm 2.6\right.$ vs. $103.4 \pm 10.4$ cells $/ \mathrm{mm}^{2}, P<0.0001$, Fig. 1$)$. In contrast, efavirenz $(50 \mathrm{mg} / \mathrm{kg})$ did not alter NF-кBp65 expression in mice cardiac tissue (data not shown). Efavirenz also did not alter caspase-3 expression in mice cardiac tissue (data not shown).

Indinavir caused focal cardiomyocyte necrosis $(4.5 \pm 0.8 \%)$. However mildronate administered together with indinavir

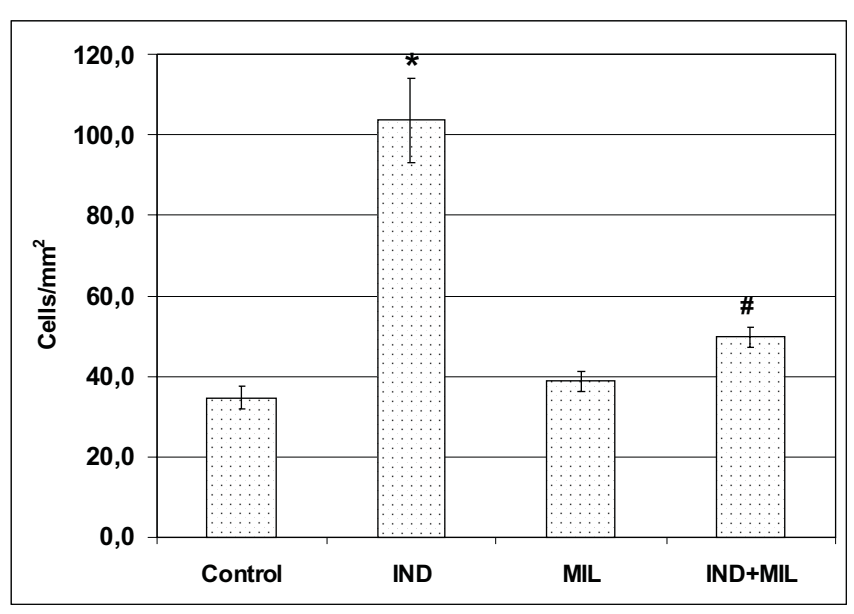

Fig. 1. Total number of nuclear factor kappaBp65 (NF-кBp65) positive cells in mice heart tissue (in nuclei of cardiomyocytes, inflammatory and endothelial cells) of saline (control, $10 \mathrm{ml} / \mathrm{kg}$ ), indinavir (IND, $50 \mathrm{mg} / \mathrm{kg}$ ), mildronate (MIL, $100 \mathrm{mg} / \mathrm{kg}$ ) groups and MIL combination with IND after two week intraperitoneal administration of drugs. Statistical significance is expressed as: ${ }^{*} P<0.05$ vs. control group, ${ }^{\#} P<0.05$ vs. IND, unpaired t-test. 
did not reduce this indinavir effect $(4.5 \pm 0.7 \%)$. Indinavir caused also focal cardiomyocyte fatty degeneration and vacuolisation, but mildronate had no effect on this (data not shown). Figure 2 shows that indinavir increased (2-fold) cellular infiltration in mice cardiac tissue $(1.9 \pm 0.3$ scores $)$. Mildronate showed only a tendency to reduce this cellular infiltration $(1.1 \pm 0.1$ vs. $1.9 \pm 0.3$ scores, $P>0.05)$. Efavirenz at dose $50 \mathrm{mg} / \mathrm{kg}$, administered for two weeks, did not cause significant histopathological changes in mice cardiac tissue (data not shown).

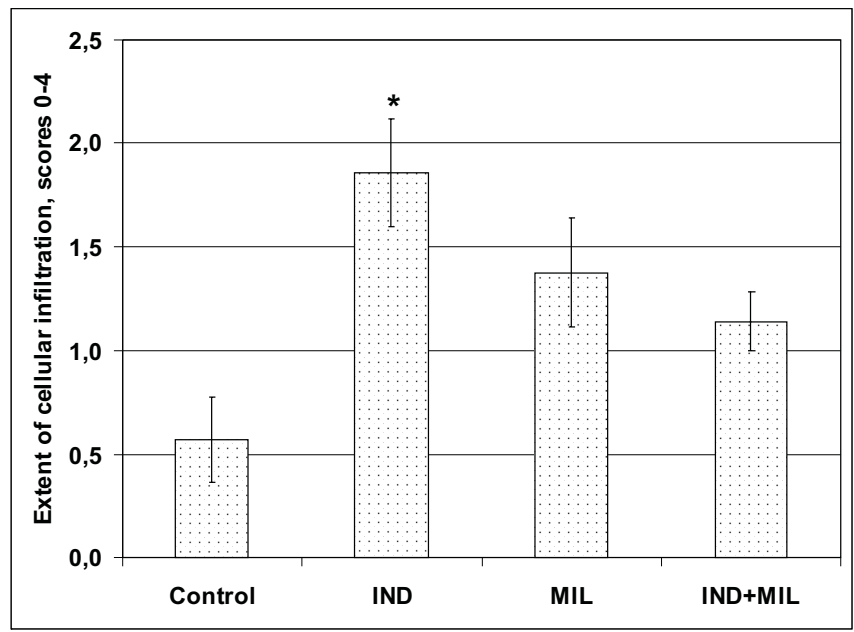

Fig. 2. The extent of limphohistyocytar infiltration in mice myocardium (values are in scores from 0 to 4). Tested drugs - indinavir (IND, 50 $\mathrm{mg} / \mathrm{kg}$ ) and mildronate (MIL, $100 \mathrm{mg} / \mathrm{kg}$ ) — were administered in mice intraperitoneally once a day during two week period. Statistical significance expressed: ${ }^{*} P<0.05$ vs. saline (control) group, Mann-Whitney U-test.

Effect of mildronate on immunohistochemical and morphological alterations in mice brain tissue. Efavirenz increased caspase- 3 expression in mice brain tissue, in comparison to the saline control group $(3.9 \pm 0.4$ vs. $2.4 \pm 0.6$ cells $/ \mathrm{mm}^{2}, P<0.05$, Fig. 3). Mildronate $(100 \mathrm{mg} / \mathrm{kg})$ per se did not change caspase- 3 expression in mice brain tissue, but it decreased efavirenz-induced caspase- 3 expression $\left(2.2 \pm 0.1\right.$ vs. $3.9 \pm 0.4$ cells $/ \mathrm{mm}^{2}, P<0.05$, Fig. 3$)$. Efavirenz increased also glial fibrillary acidic protein (GFAP) expression, compared to the saline control group $(40.0 \pm 4.8$ vs. $23.0 \pm 5.1$ cells $/ \mathrm{mm}^{2}, P<0.05$, Fig. 4 ). Mildronate $p e r$ se did not increase GFAP expression, while in combination with efavirenz it reduced GFAP expression induced by efavirenz $\left(25.1 \pm 1.8\right.$ vs. $40.0 \pm 4.8$ cells $/ \mathrm{mm}^{2}, P<0.01$, Fig. 4). Our results showed that efavirenz caused also small degenerative changes in mice brain tissue, which were manifested as focal neuronal and perivascular edema, and perivascular cellular infiltration. Mildronate protected brain tissue against efavirenz-induced neuronal pericellular and perivascular edema (data not shown).

Effect of mildronate on immunohistochemical and morphological alterations in mice liver tissue. Efavirenz (50 $\mathrm{mg} / \mathrm{kg}$ ) like saline (control) and mildronate $(100 \mathrm{mg} / \mathrm{kg}) \mathrm{did}$ not alter caspase-3 expression in mice liver tissue (data not shown). Efavirenz caused small degenerative alterations in

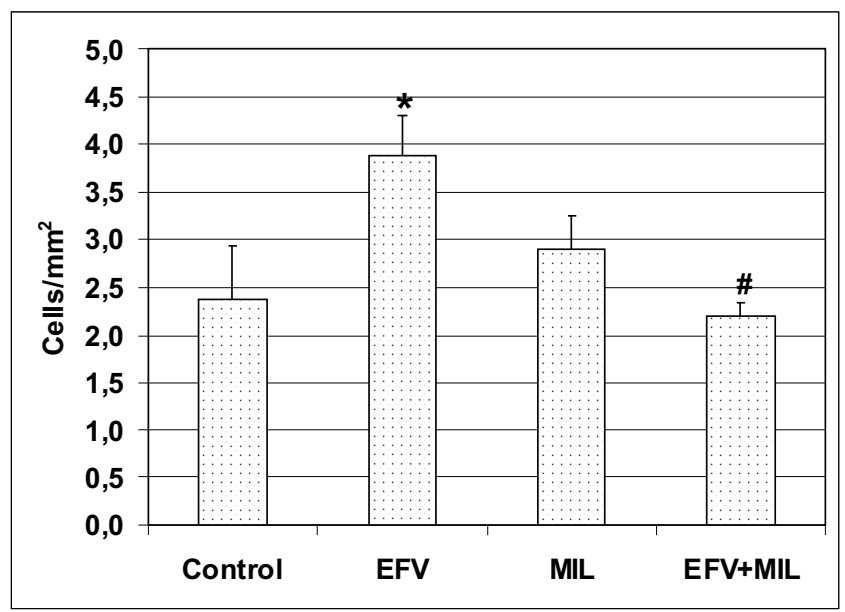

Fig. 3. Total number of caspase-3 positive neurons (cells $/ \mathrm{mm}^{2}$ ) in mice brain tissue of saline (control, $10 \mathrm{ml} / \mathrm{kg}$ ), efavirenz (EFV, $50 \mathrm{mg} / \mathrm{kg}$ ), mildronate (MIL, $100 \mathrm{mg} / \mathrm{kg}$ ), and MIL + EFV groups after two week intraperitoneal administration of drugs. Statistical significance is expressed as: ${ }^{*} P<0.05$ vs. saline control group, ${ }^{\#} P<0.05$ vs. EFV group, unpaired t-test or Mann-Whitney U-test.

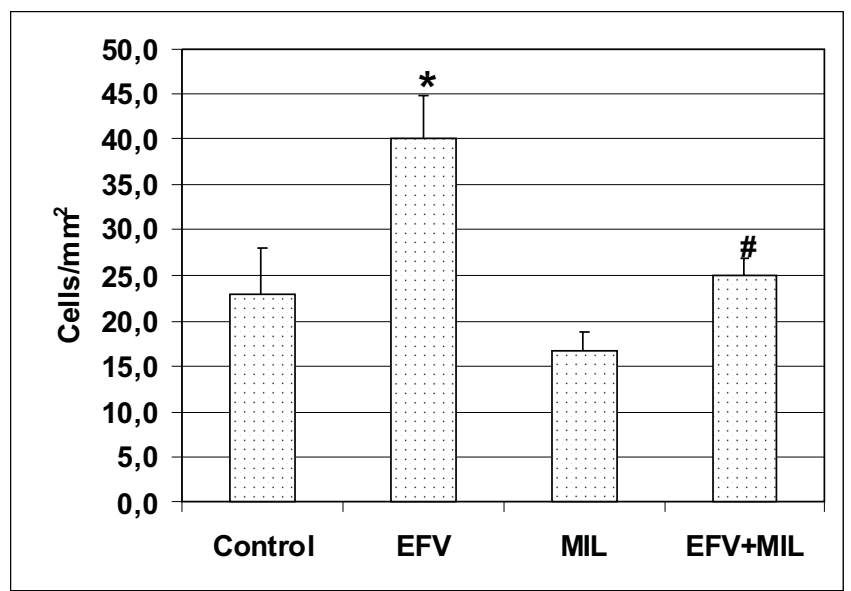

Fig. 4. Total number of glial fibrillary acidic protein (GFAP) positive cells (cells $/ \mathrm{mm}^{2}$ ) in mice brain tissue of saline (control, $10 \mathrm{ml} / \mathrm{kg}$ ), efaviren (EFV, $50 \mathrm{mg} / \mathrm{kg}$ ), mildronate (MIL, $100 \mathrm{mg} / \mathrm{kg}$ ), and MIL + EFV groups after two week intraperitoneal administration of drugs. Statistical significance is expressed as: ${ }^{*} P<0.05$ vs. control group, ${ }^{\#} P<0.05$ vs. EFV group, unpaired t-test or Mann-Whitney U-test.

mice liver tissue, manifested as small hepatocyte vacuolar and fatty degeneration, dilated portal tracts, infiltration of inflammatory cells, and increased number of megakaryocytes. The obtained alterations were evaluated as histological activity index (HAI) with scores: $3.1 \pm 0.3$ vs. $0.9 \pm 0.3$ in the control group, $(P<0.0001)$, Fig. 5. Mildronate $(100$ $\mathrm{mg} / \mathrm{kg}$ ) per se caused small hepatocyte vacuolar and focal fatty degeneration (scores $1.8 \pm 0.2$ vs. $0.9 \pm 0.3$ of the control, $P>0.05$, Fig. 5), while in combination with efavirenz it had a tendency to decrease the evafirenz-induced increase in HAI: $2.6 \pm 0.2$ vs. $3.1 \pm 0.3$ scores, $P>0.05$, Fig. 5 .

\section{DISCUSSION}

In the present study, we examined the influence of mildronate on the toxic effects of indinavir and efavirenz, 


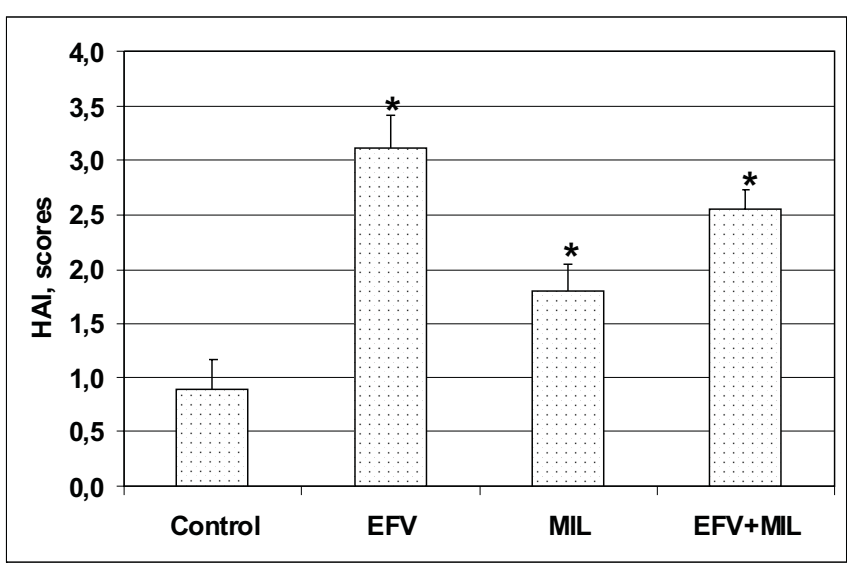

Fig. 5. Histological activity index (HAI, in scores) in mice liver tissue of saline (control, $10 \mathrm{ml} / \mathrm{kg}$ ), efavirenz (EFV, $50 \mathrm{mg} / \mathrm{kg}$ ), mildronate (MIL, $100 \mathrm{mg} / \mathrm{kg}$ ) groups, and EFV + MIL after two week intraperitoneal administration of drugs. Statistical significance is expressed as: ${ }^{*} P<0.05$ vs. control group, unpaired t-test.

anti-HIV drugs of the PI and NNRTI classes, respectively. The morphological and immunohistochemical examination of mice tissue after a two-week administration regimen of these drugs showed that indinavir (PI) significantly affected cardiac tissue: it increased the expression of NF- $\kappa \mathrm{Bp} 65$, as well as induced cardiomyocyte necrosis, fatty degeneration and vacuolisation, indicating inflammatory and degenerative responses in cardiac cells. Mildronate (at a dose of $100 \mathrm{mg} / \mathrm{kg}$ ) effectively reduced the overexpression of NF- $\kappa \mathrm{Bp} 65$, but it had no effect on cardiomyocyte necrosis, fatty degeneration and vacuolisation. Efavirenz (NNRTI) did not have a toxic effect on heart tissue, as we observed neither an increase in NF- $\mathrm{BBp} 65$ and caspase- 3 expression, nor morphological alterations.

In the cardiotoxicity model, the tested drugs of PI and NNRTI classes showed distinct effects in comparison to those obtained previously in NRTI drug studies. Mildronate clearly protected against the action of NRTIs, such as azidothymidine, the most toxic agent among anti-HIV drugs, as well as lamivudine and stavudine, since mildronate reduced

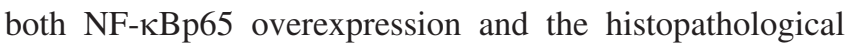
changes in mice myocardium (Klusa et al., 2006; Isajevs et $a l ., 2007)$. The mechanism of NRTIs is demonstrated to be provided via mitochondria-compromising effects (Badley et al., 2003). Hence, the successful cardioprotection known as a very important property of mildronate, can be attributed to mitochondria-targeting, since mildronate's ability to prevent mitochondrial respiratory chain functions was found by us previously (Pupure et al., 2008).

The mitochondrial mechanism for drugs of PI and NNRTI classes was not strongly demonstrated. In our study we showed that PI and NNRTI affect mouse tissue in different ways. Firstly, mildronate protected indinavir-induced inflammation in cardiomyocytes but not morphological alterations. Secondly, efavirenz did not cause significant cardiotoxicity. Therefore, we may speculate, on the one hand, that different tissue sensitivity to anti-HIV drugs exists, and, on the other hand, suggest their different mechanisms at the cellular level. Probably, protection of indinavir-induced NF-kBp65 expression in cardiac tissue caused by mildronate may be explained rather by its anti-inflammatory activity, and less by its anti-degenerative activity. Similarly, in hepatic tissue mildronate acted mostly against inflammatory effects caused by efavirenz.

In mice brain tissue, efavirenz caused pathological changes, such as increased expression of caspase- 3 and GFAP, which were effectively reduced by mildronate. Moreover, mildronate also reduced efavirenz-induced pericellular and perivascular edema and cellular infiltration. The overexpression of caspase- 3 shows apoptotic processes in neurons, while that of GFAP indicates appearance of reactivity of glial astrocytes. Since mildronate successfully normalised both these pathological neuronal and glial processes caused by efavirenz, we suggest mildronate's neuroprotective effects against efavirenz neurotoxicity. In literature there is little data about the influence of efavirenz on the CNS. It was shown that efavirenz may inhibit creatine kinase activity in the brain (Streck et al., 2008). Function of this enzyme is to catalyze the conversion of creatine to phosphocreatine by applying itself in the consumption of adenosine triphosphate, hence playing a significant role in cell energy homeostasis (Streck et al., 2008). Recently creatine kinase together with lactate dehydrogenase, neuron specific enolase, GFAP and others has been proposed as potential markers of brain injury (Korfias et al., 2009). The influence of mildronate on brain creatine kinase activity has not yet been shown; one may only suggest its protective influence on this enzyme.

In conclusion, the obtained data demonstrate that daily two-week intraperitoneal administration (dose of $50 \mathrm{mg} / \mathrm{kg}$, in mice) of indinavir, a representative of PI class, showed weak cardiotoxic effects, while efavirenz, a representative of NNRTI class, lacked this toxicity. However, efavirenz showed marked alterations in mice brain tissue and weak toxic effects in liver tissue. Mildronate protected from indinavir-induced cardiotoxicity and efavirenz-induced neurotoxicity. Distinct tissue sensitivity and specificity to these drugs, on one hand, and different intensity of mildronate's ability to protect tissue against drug toxic effects, on the other hand, indicate usefulness of mildronate as a protective agent in clinical use of indinavir and/or efivarenz as antiHIV/anti-AIDS drugs. Probably tissue-protective activity of mildronate involves not only mitochondria-regulating but also other cellular mechanisms.

\section{ACKNOWLEDGEMENTS}

This work was supported by Latvian Council of Science Grant No. 05-1418, ESF Grant ESS2004/3, Grant of the Agreement No. 2007/2362 between the University of Latvia and the Joint Stock Company "Grindeks". L'OREAL Latvian "For Women In Science" fellowship with the support of the Latvian National Commission for UNESCO and the Latvian Academy of Sciences. 


\section{REFERENCES}

Akasaka, Y., Morimoto, N., Ishihawa, Y., Fujita, K., Ito, K., KimuraMatsumoto, M., Ishiguro, S., Morita, H., Kobayashi, Y., Ishii, T. (2006). Myocardial apoptosis associated with the expression of proinflammatory cytokines during the course of myocardial infarction. Mod. Pathol., 19(4), 588-598.

Allen, N.J., Barres, B.A. (2009). Glia - more than just brain glue. Nature, 457(7230), 675-677.

Badley, A.D., Roumier, T., Lum, J.J., Kroemer, G. (2003). Mitochondrion-mediated apoptosis in HIV-1 infection. Trends Pharmacol. Sci., 24(6), 298-305.

Caron, M., Auclairt, M., Vissian, A., Vigouroux, C., Capeau, J. (2008). Contribution of mitochondrial dysfunction and oxidative stress to cellular premature senescence induced by antiretroviral thymidine analogues. Antivir. Ther., 13(1), 27-38.

Corcuera Pindado, M.T., Lopez Bravo, A., Martinez-Rodriguez, R., Picazo Talavera, A., Gomez Aguado, F., Roldan Contreras, M., Perez Alvarez, M.J., Fernandez Garcia, A., Alonso Martin, M.J. (1994). Histochemical and ultrastructural changes induced by zidovudine in mitochondria of rat cardiac muscle. Eur. J. Histochem., 38(4), 311-318.

Di Stefano, A., Caramori, G., Oates, T., Capelli, A., Lusuardi, M., Gnemmi, I., Ioli, F., Chung, K. F., Donner, C. F., Barnes, P. J., Adcock, I. M. (2002). Increased expression of nuclear factor- $\kappa \mathrm{B}$ in bronchial biopsies from smokers and patients with COPD. Eur. Respir. J., 20(3), 556-563.

Enari, M., Sakahira, H., Yokoyama, H., Okawa, K., Iwamatsu, A., Nagata, S. (1998). A caspase-activated DNase that degrades DNA during apoptosis, and its inhibitor ICAD. Nature, 391(6662), 43-50.

Gown, A.M., Willingham, M.C. (2002) Improved detection of apoptotic cells in archival paraffin sections: Immunohistochemistry using antibodies to cleaved caspase 3. J. Histochem. Cytochem., 50(4), 449-454.

Holmberg, B., Rosengren, L., Karlsson, J.E., Johnels, B. (1998). Increased cerebrospinal fluid levels of neurofilament protein in progressive supranuclear palsy and multiple-system atrophy compared with Parkinson's disease. Mov. Disord., 13(1), 70-77.

Hong-Brown, L.Q., Brown, C.R., Lang, C.H. (2004). Indinavir impairs protein synthesis and phosphorylations of MAPKs in mouse $\mathrm{C} 2 \mathrm{C} 12$ myocytes. Amer. J. Physiol. Cell. Physiol., 287(5), C1482-C1492.

Isajevs, S., Pupure, J., Gordjušina, V., Kratovska, A., Taivans, I., Vīksna, L., Kalviňš, I., Kluša, V. (2007). Mildronate protects stavudine and lamivudine induced cardiotoxicity. Proc. Latvian Acad. Sci., Section B, 61(1/2), 26-32.

Ishak, K., Baptista, A., Bianchi, L., Callea, F., De Groote, J., Gudat, J., Gudat, F., Denk, H., Desmet, V., Korb, G., MacSween, R.N., et al. (1995).
Histological grading and staging of chronic hepatitis. J. Hepatol., 22(6), 696-699.

Klusa, V., Pupure, J., Isajevs, S., Rumaks, J., Gordjushina, V., Kratovska, A., Taivans, I., Svirskis, S., Viksna, L., Kalvinsh, I. (2006). Protection of azidothymidine-induced cardiopathology in mice by mildronate, a mitochondria-targeted drug. Basic Clin. Pharmacol. Toxicol., 99(4), 323-328.

Kontorinis, N., Dieterich, D. (2003). Hepatotoxicity of antiretroviral therapy. AIDS Rev., 5(1), 36-43.

Korfias, S., Papadimitriou, A., Stranjalis, G., Bakoula, C., Daskalakis, G., Antsaklis, A., Sakas, D.E. (2009). Serum biochemical markers of brain injury. Mini Rev. Med. Chem., 9(2), 227-234.

Miller, K.D., Cameron, M., Wood, L.V., Dalakas, M.C., Kovacs, J.A. (2000). Lactic acidosis and hepatic steatosis associated with use of stavudine: Report of four cases. Ann. Intern. Med., 133(3), 192-196.

Peters, B. S., Winer, J., Landon, D. N., Stotter, A., Pinching, A. J. (1993). Mitochondrial myopathy associated with chronic zidovudine therapy in AIDS. Q. J. Med., 86(1), 5-15.

Pupure, J., Fernandes, M.A.S., Santos, M.S., Moreno, A.J.M., Kalvinsh, I., Klusa, V., Oliveira, C.R. (2008). Mitochondria as the target for mildronate's protective effects in azidothymidine (AZT)-induced toxicity of isolated rat liver mitochondria. Cell Biochem. Funct., 26(5), 620-631.

Rahman, I., MacNee, W. (2000) Oxidative stress and regulation of glutathione in lung inflammation. Eur. Respir. J., 16(3), 534-554.

Streck, E.L., Scaini, G., Rezin, G.T., Moreira, J., Fochesato, C.M., Romćo, P.R. (2008). Effects of the HIV treatment drugs nevirapine and efavirenz on brain creatine kinase activity. Metab. Brain. Dis., 23(4), 485-492.

Szabados, E., Fisher, G. M., Toth, K., Csete, B., Nemeti, B., Trombitas, K., Habon, T., Endrei, D., Sumegi, B. (1999). Role of reactive oxygen species and poly-ADP-ribose polymerase in the development of AZT-induced cardiomyopathy in rat. Free Radic. Biol. Med., 27(9-10), 1103-1113.

Tullberg, M., Rosengren, L., Blomsterwall, E., Karlsson, J.E., Wikkelso, C. (1998). CSF neurofilament and glial fibrillary acidic protein in normal pressure hydrocephalus. Neurology, 50(4), 1122-1127.

Viengchareun, S., Caron, M., Auclair, M., Kim, M.J., Frachon, P., Capeau, J., Lombčs, M., Lombčs, A. (2007). Mitochondrial toxicity of indinavir, stavudine and zidovudine involves multiple cellular targets in white and brown adipocytes. Antivir. Ther., 12(6), 919-929.

Walker, U.A., Setzer, B., Venhoff, N. (2002). Increased long-term mitochondrial toxicity in combinations of nucleoside analogue reverse-transcriptase inhibitors. AIDS, 16(16), 2165-2173.

White, A.J. (2001). Mitochondrial toxicity and HIV therapy. Sex Transm. Infect., 77(3), 158-173.

Received 11 November 2009

\section{MILDRONĀTA EFEKTI INDINAVĪRA UN EFAVIRĒNA IZRAISĪTAJOS TOKSICITĀTES MODEL̨OS PELĒM}

Pētījuma uzdevums bija noskaidrot mildronāta spēju pasargāt peḷu sirds, smadzeṇu un aknu audus no anti-HIV vielu indinavīra (proteāzes inhibitora) un efavirēna (ne-nukleozīdu analogu reversās transkriptāzes inhibitora) izraisītajām morfoloğiskajām un imunohistokịmiskajām pārmaiņām. Indinavīrs (50 mg/kg, divu nedēḷ intraperitoneāla ievadīšana) peḷu sirds audos izraisīja iekaisuma un deǵeneratīvas pārmaiņas, kas izpaudās kā palielināta kodola faktora kappaBp65 (NF-kBp65) ekspresija, kardiomiocītu nekroze un šūnu infiltrācija. Efavirēns (50 $\mathrm{mg} / \mathrm{kg}$, divu nedēlu intraperitoneāla ievadīšana) neizraisīja patoloğiskas izmaiņas peḷu sirds audos, taču izraisīja izteiktu apoptozi un astrogliozi smadzeṇu audos un nelielas deǵeneratīvas pārmaiṇas peḷu aknu audos. Mildronāts (100 mg/kg, ievadīts intraperitoneāli vienlaicīgi ar anti-HIV vielām) uzrādīja protektējošas īpašības, būtiski samazinot indinavīra un efavirēna efektus tajos audos, kuros šīs vielas uzrādīja toksicitāti. Iegūtie dati, no vienas puses, demonstrē pētīto anti-HIV vielu atškirīìgo ietekmi uz dažādu audu funkcijām, un, no otras puses, atškirīgo mildronāta protektējošo efektu, kam var būt terapeitiska nozīme, izmantojot mildronātu kā indinavīra kardiotoksicitātes un efivarēna neirotoksicitātes protektētāju. 